\title{
KINERJA PENGURUS KOPERASI UNIT DESA (KUD)
}

\author{
Paulus \\ Fakultas Ilmu Sosial dan Ilmu Politik Universitas Kapuas Sintang \\ Jln. Y.C. Oevang Oeray No. 92 Sintang, Kalimantan Barat \\ Email:paulus_semari@yahoo.com
}

\begin{abstract}
Abstrak: Permasalahan penelitian ini adalah kinerja Pengurus KUD Dharma Bhakti di Kecamatan Binjai Hilir Kabupaten Sintang. Tujuan penelitian adalah untuk mengetahui dan mendiskripsikan kinerja pengurus. Manfaat yang dihasilkan dari penelitian diharapkan memiliki kegunaan baik secara teoritis maupun secara praktis. Ruang lingkup penelitian ini adalah kinerja dengan aspek-aspek yang diteliti antara lain : 1) tugas pokok dan fungsi pengurus, 2) Dimensi Kinerja, 3) motivasi kerja, dan 4) fasilitas kerja. Jenis penelitian ini adalah deskriptif dengan analisis kualitatif. Subjek penelitian terdiri dari yaitu : 1) Ketua Pengurus, 2) Ketua Pengawas, 3) Anggota. Penetapan subjek penelitian ketua pengawas dan ketua pengurus menggunakan metode purposive sampling, sedangkan anggota menggunakan metode incidental sampling. Teknik pengumpulan data dengan wawancara, observasi dan dokumentasi. Pengurus terdiri dari ketua pengurus, sekretaris, dan bendahara yang memiliki tupoksi masing-masing yang mengacu kepada peraturan perkoperasian pada umumnya. Berdasarkan tupoksi pengurus melaksanakan operasional usaha koperasi dengan memperhatikan dimensi kinerja kualitas, kuantitas, kecepatan, kerja, kerja sama, kepemimpinan, dan komunikasi. Pengurus hal-hal yang memotivasi pengurus yaitu rasa solidaritas, honor pengurus, dan penguatan dari anggota berupa kepercayaan yang diberikan anggota untuk mengelola. Pengelolaan KUD didukung oleh fasilitas-fasilitas yang diperlukan untuk bekerja dalam melaksanakan pekerjaan administrasi perkantoran.
\end{abstract}

Kata Kunci : Kinerja, Pengurus, KUD

Manusia merupakan faktor produksi yang dinamis di dalam organisasi karena dapat berubah dalam hal perilaku dan kontribusinya terhadap organisasi. Perubahan tersebut karena manusia memiliki akal budi serta kondisi fisik yang ada. Tidak seperti halnya faktor produksi lain seperti bahan baku, uang, mesin dan sebagainya yang cenderung dapat diketahui pasti kinerjanya. Situasi pada masa sekarang ini menuntut manusia untuk dapat melakukan manajemen yang baik di dalam pemanfaatan sumber daya lainnya. Pada organisasi maka manusia tersebut harus di atur dan dikendalikan oleh manusia lainnya sehingga dapat memberikan kinerja sesuai yang diharapkan.

Kinerja atau hasil kerja sumber daya manusia organisasi menjadi kunci keberhasilan dan kemajuan sebuah organisasi. Kinerja yang tinggi akan memberikan kontribusi yang lebih banyak dibanding kinerja yang rendah. Konsekuensi kinerja selanjutnya pada organisasi selanjutnya adalah mempengaruhi kualitas dan kuantitas output (produk) yang dihasilkan seseorang sehingga kinerja yang tinggi biasa disebut produktif, dan kinerja yang rendah dikatakan kurang produktif. Dampak kinerja selanjutnya pada organisasi adalah berkaitan cash flow (aliran dana). Kinerja para pegawai/karyawan pada akhirnya menghasilkan kinerja organisasi. Biasa kinerja yang rendah menjadi tidak efisien sehingga sehingga terjadi pemborosan biaya-biaya sementara output rendah.
Dengan demikian kemajuan dan eksistensi sebuah organisasi tergantung kepada kinerja organisasi, dan kinerja organisasi dihasilkan dari kinerja-kinerja individu-individu yang menjalankan pekerjaannya pada organisasi tersebut. Ada banyak faktor penyebab sebuah organisasi memiliki kinerja yang rendah, beberapa diantaranya adalah budaya kerja, kepemimpinan, kurangnya perhatian dan pembinaan serta manajemen dan penerapannya yang kurang baik. Faktor sangat penting sebetulnya terletak pada kemampuan pemimpin di dalam memimpin organisasi. Sebuah organisasi yang berkembang dan sebaliknya merupakan cerminan kualitas dari pemimpinnya walaupun ada faktor lain, namun pemimpin memegang peran sangat penting dan strategis.

Koperasi Unit Desa (KUD) merupakan salah satu lembaga atau organisasi yang bergerak dalam pelayanan kepada masyarakat, khususnya para anggotanya. Berbadan hukum koperasi dan menjalankan usaha berdasarkan Anggaran Dasar dan Anggaran Rumah Tangga yang telah ditetapkan saat pendiriannya. KUD melakukan pengelolaan keuangan para anggotanya untuk mewujudkan kesejahteraan bersama. Pengelolaan keuangan menuntut sumber daya manusia yang sangat profesional, mengingat mengurus keuangan harus tepat, cepat, teliti, transparan dan akuntabel. Apabila beberapa poin tersebut tidak mampu terpenuhi maka akan berdampak pada kinerja 
KUD tersebut sehingga dapat muncul berbagai persoalan.

KUD sekarang ini banyak didirikan dalam rangka mengakomodir kepentingan perusahaan dan para petani plasma pada perkebunan kelapa sawit. Salah satu KUD yang ada di Kabupaten Sintang adalah KUD Dharma Bhakti yang berada di Kecamatan Binjai HILIR. KUD Dharma Bhakti berdiri pada tanggal 15 Desember 2010 sebagai wadah untuk pengelolaan perkebunan kelapa sawit sistem kemitraan dengan perusahaan kelapa sawit PT. Bonti Permai Jayaraya. Berdasarkan laporan Pertanggungjawaban Pengurus pada Rapat Anggota Tahunan (RAT), jumlah anggota sebanyak 273 orang. Itu artinya ada 273 kampling (541 hektar) milik petani plasma pada PT. Bonti Permai Jayaraya. Jumlah anggota tersebut dalam 3 (tiga) tahun terakhir mulai dari tahun 2016-2018 masih tetap, 273 orang belum ada penambahan ataupun pengurangan, karena anggota tersebut berdasarkan jumlah kapling kebun kepala sawit yang ada. Untuk sementara belum ada penambahan areal perkebunan baru sehingga jumlahnya masih tetap.

Koperasi tersebut dalam pengelolaan berdasarkan informasi dari pengelola dan anggota dalam operasinya dikelola oleh tenaga pengelola yang disebut Pengurus koperasi. Pengurus koperasi inilah yang menjalankan pelaksanaan operasional sehari-hari. Berdasarkan buku laporan RAT KUD Dharma Bhakti tahun buku 2018, jumlah Pengurus sebanyak 3 (orang) yang terdiri dari 1 orang ketua, 1 orang bendahara, dan 1 orang sekretaris. Sebagaimana ketentuan koperasi, maka KUD Dharma Bhakti juga memiliki Badan Pengawas yang terdiri dari Ketua Pengawas, dan 2 orang anggota Pengawas. Berdasarkan informasi dari anggota koperasi, masih ada kendala berkaitan dengan kinerja pengurus koperasi tersebut yaitu kurangnya transparansi dan penjelasan mengenai keuangan anggota yang dikelola pengurus tersebut sehingga anggota merasa kurang puas dengan pelayanan yang diberikan. Berdasarkan uraian diatas peneliti tertarik untuk meneliti lebih lanjut mengenai kinerja Pengurus Koperasi Unit Desa (KUD) Dharma Bhakti sehingga harapannya dapat mengungkap dan mengetahui berbagai aspek yang berkaitan dengan kinerja pengurus tersebut yang selanjutnya dapat bermanfaat bagi berbagai pihak.

Kinerja merupakan kemampuan seseorang dalam bekerja yang dilihat dari seberapa banyak dan berkualitasnya hasil dicapai dalam aktivitas kerja. Menurut Mahsun (2006 : 25), "Kinerja adalah gambaran mengenai tingkat pencapaian pelaksanaan suatu kegiatan/program/ kebijakan dalam mewujudkan sasaran, tujuan, misi dan visi organisasi". Kinerja di dalam suatu organisasi atau lembaga merupakan tolok ukur daripada pencapaian tujuan yang telah ditetapkan karena dengan demikian akan terlihat pelaksanaan program yang telah dirumuskan melalui kebijakan lembaga apakah terealisasi dengan baik atau tidak. Sementara menurut Hasibuan (2002 : 94), kinerja adalah "suatu hasil kerja yang dicapai seseorang dalam melaksanakan tugas - tugas yang dibebankan padanya yang didasarkan atas kecakapan, pengalaman, dan kesungguhan, serta waktu". Kinerja akan menentukan tingkat keberhasilan atau capaian kerja seseorang atau unit kerja di dalam organisasi. Kinerja seseorang dipengaruhi oleh faktor internal dan eksternal yang dimiliki dan dihadapi oleh individu. Faktor internal berkaitan dengan hal-hal yang berhubungan dengan pribadi masing-masing antara lain kemampuan fisik dalam bekerja, pengetahuan dan keterampilan serta pola pikir seseorang terhadap pekerjaannya.

Seseorang yang memiliki tingkat pendidikan yang lebih tinggi dari rekan kerjanya seharusnya memiliki cara dan kemampuan kerja yang berbeda sehingga kinerjanya lebih baik. Seseorang yang berpendidikan memiliki kemampuan konseptual yang lebih baik dan mampu mencari solusi dan pemecahan masalah dengan melakukan analisis secara terstruktur dan sistematis. Sedangkan aspek keterampilan berkaitan dengan kemampuan seseoarang bekerja menggunakan segenap anggota tubuhnya untuk menyelesaikan suatu pekerjaan. Semakin terampilan seseorang menggunakan anggota tubuhnya di dalam bekerja maka kecepatan, keakuratan, kualitas dan kuantitas kerja tentu semakin meningkat. Sementara itu hal lain yang termasuk faktor eksternal yang dapat mempengaruhi kinerja seseorang adalah faktor lingkungan, baik lingkungan tempat tinggal maupun lingkungan tempat bekerja.

Menurut Mangkunegara (2005:15), faktorfaktor kinerja terdiri faktor internal dan faktor eksternal. Faktor internal (disposisional), yaitu faktor yang dihubungkan dengan sifat-sifat seseorang. Faktor eksternal, yaitu faktor faktor yang mempengaruhi kinerja seseorang yang berasal dari lingkungan, seperti perilaku, sikap, dan tindakan-tindakan rekan kerja, bawahan atau pimpinan, fasilitas kerja, dan iklim organisasi. Faktor-faktor internal dan eksternal ini merupakan jenis $\neg$ jenis atribusi yang mempengaruhi kinerja seseorang. Secara lebih jelas faktor faktor penentu prestasi kerja individu dalam organisasi adalah menurut Mangkunegara (2005 : 16-17) adalah Faktor Individu. Secara psikologis, individu yang normal adalah individu yang memiliki integritas yang tinggi antara fungsi psikis dan fisiknya. Konsentrasi yang baik ini merupakan modal utama individu untuk mampu mengelola dan mendayagunakan potensi dirinya secara optimal dalam melaksanakan kegiatan atau aktivitas kerja. Faktor Lingkungan. Faktor lingkungan kerja organisasi sangat menunjang bagi individu dalam 
mencapai prestasi kerja. Faktor lingkungan organisasi yang dimaksud antara lain uraian jabatan yang jelas, autoritas yang memadai, target kerja yang menantang, pola komunikasi kerja efektif, hubungan kerja harmonis, iklim kerja respek dan dinamis, peluang berkarier dan fasilitas kerja yang relatif memadai.

Menurut Hendrojogi (2005:20), bahwa koperasi merupakan suatu wadah bagi golongan masyarakat yang berpenghasilan rendahyang dalamrangkausaha untuk memenuhi kebutuhan hidupnyaberusahameningkatkan tingkat hidup. Koperasi merupakan organisasi sosial sekaligus ekonomi yang bertujuan untuk mengakomodir kepentingan anggota untuk mencapai kesejahteraan anggota. Melalui koperasi kepentingan bersama dapat diwujudkan sehingga berbagai sumber daya dapat dikelola melalui wadah koperasi. Menurut UndangUndang Nomor 25 Tahun 1992, Koperasi adalah "badan usaha yang beranggotakan orangseorang atau badan hukum koperasi yang melandaskan kegiatannya berdasarkan prinsip koperasi sekaligus sebagai gerakan ekonomi rakyat yang berdasar atas dasar kekeluargaan". Dengan demikian koperasi lebih mengutamakan anggota dari pada kumpulan modal. Tanpa partisipasi anggota koperasi tidak dapat berkembang dengan baik. Oleh karena itu lembaga koperasi akan berkembang tergantung keaktifan dan kualitas anggota dalam menjalankan kewajibannya.

Kerjasama alam koperasi di dasarkan pada rasa persamaan derajat,dan kesadaran para anggotanya. Koperasi merupakan wadah demokrasi ekonomi dan sosial. Koperasi adalahmilikbersama paraanggota, pengurus maupun pengelola. Usaha tersebut diatur sesuai dengan keinginan para anggota melalui musyawarah rapat anggota.Tugas utama perusahaan koperasi adalah menunjang kegiatan usaha para anggotanya dalam rangka meningkatkan kepentingan perekonomian para anggotanya melalui pengadaan barang dan jasa yang dibutuhkannya, yang sama sekali tidak tersedia di pasar, atau ditawarkan dengan harga, mutu atau syarat-syarat yang lebih menguntungkan daripada yang ditawarkan pada anggota di pasar atau oleh badan-badan resmi. Agar perusahaan koperasi dapat menyediakan barang dan jasa yang dibutuhkan oleh perekonomian para anggotanya.

Menurut Arifinal Chaniago dan Ijod Sirdjudin (Widayanti 2005:25) definisi Koperasi Unit Desa (KUD) adalah "suatu organisasi ekonomi yang berwatak sosial dan merupakan wadah bagi perkembangan berbagai kegiatan ekonomi masyarakat pedesaan yang diselenggarakan oleh dan untuk masyarakat itu sendiri”.Adapun pengertian KUD menurut Pandji
Anaroga dan Ninik W, (1983:18) adalah “Koperasi unit desa adalah sebagai lembaga ekonomi tingkat pedesaan yaitu melayani kebutuhan sarana produksi pertanian dan sekaligus menampung hasilhasilnya." Berdasarkan definisi yang dikemukakan para ahli diatas dapat diketahui bahwa KUD merupakan organisasi dalam operasional berdasarkan prinsip-prinsip koperasi untuk mengakomodir kepentingan para petani di pedesaan dalam hal menyediakan sarana dan prasarana pertanian untuk pemeliharaan tanaman, panen maupun paska panen. Koperasi Unit Desa (KUD) dibentuk atas dasar kesamaan persepsi dan kebutuhan petanimengenai kemudahan untuk memperoleh sarana dan prasarana produksi pertanian/perkebunan dengan melandaskan kegiatannya berdasarkan prinsip koperasi sekaligus sebagaigerakan ekonomi rakyat yang berdasar atas asas kekeluargaan. Pendirian KUD memilikitujuan untuk melayani berbagai kepentingan masyarakat pedesaan, bersifat serbausaha dengan wilayah kerja mencakup unit desa. KUD berperan sebagai lembagapelayanan di desa yang dituntut untuk menampung, mengembangkan, danmembina berbagai kegiatan usaha anggotanya secara efektif dan efisien sehinggatujuan KUD dapat tercapai.

Berdasarkan Undang - Undang Nomor 25 tahun 1992 tentang perkoperasian, disebutkan dalam pasal 21 bahwa perangkat organisasi koperasi terdiri dari : “1). Rapat Anggota, 2). Pengurus, dan 3). Pengawas". Pengurus adalah bagian di dalam struktur organisasi koperasi dan menduduki posisi tingkat tertinggi kedua setelah Rapat Anggota, dan pengawas adalah mitra sejajar pengurus yang bertugas mengawasi jalan penyelenggaraan kegiatan koperasi. Pengurus adalah pelaksana tugas harian atau yang menjalankan operasional usaha koperasi. Dalam struktur dapat saja dibentuk ketua pengurus, wakil, sekretaris dan bendahara. Untuk membantu kegiatan operasional, pengurus dapat pula mengangkat beberapa orang pegawai koperasi. Sebagaimana tercantum di dalam Undang Undang Nomor 25 Tahun 1992 tentang Koperasi pasal 21, Pengurus merupakan unsur dari perangkat organisasi Koperasi. Selanjutnya disebutkan pada pasal 30 ayat a bahwa Pengurus bertugas mengelola Koperasi dan Usahanya. kemudian ditegaskan pada pasal 32 bahwa Pengurus dapat mengangkat Pengelola yang diberi wewenang dan kuasa untuk mengelola usaha.

Keberadaan pengurus koperasi sangat penting terhadap berdirinya suatu koperasi, sejahtera atau tidaknya anggota juga tergantung bagaimana pengurus mengelola koperasi tersebut. Pengurus koperasi mempunyai hak dan kewajiban seperti halnya anggota, hak dan kewajiban tersebut diatur dalam Anggaran Dasar (AD) koperasi. Menurut Subandi (2010 : 56), kedudukan, fungsi, 
Pengurus koperasi baik secara pribadi maupun sebagai kolektif leader adalah pemegang kuasa/ amanah Rapat Anggota (RA). Dalam mengelola/ memimpin, sesuai kedudukan tersebut untuk pertama kali, susunan dan nama anggota pengurus dicantumkan dalam Akte Pendirian (AP) dengan masa jabatan paling lama 5 (lima) tahun, bagi yang sudah habis masa jabatannya dapat dipilih kembali. Fungsi, Fungsi pengurus koperasi memang cukup besar, dalam perannya sebagai pemimpin organisasi badan usaha koperasi yang telah memperoleh kepercayaan dari anggota, maka tidak bisa lepas dari pengawasan dan tuntunan untuk memimpin koperasinya secara baik. Tugas, Pengurus koperasi biasanya bertugas selama 3 tahun. Adapun tugas-tugasnyadalam garis besarnya adalah Mengelola koperasi dan usahanya; Mengajukan rancangan rencana kerja anggaran pendapatan dan belanja koperasi; Menyelenggarakan rapat anggota; Mengajukan laporan keuangan dan laporan pertanggungjawaban pelaksanaan tugas. Memelihara buku daftar anggota dan pengurus.

Pengurus koperasi merupakan organ terpenting dan strategis di dalam menjalankan dan mengendalikan lembaga koperasi. Walaupun di dalam struktur organisasi bukan pengurus yang tertinggi melainkan Rapat Anggota, tetapi dalam prakteknya seolah-olah penguruslah yang tertinggi, karena pengurus yang bertindak secara hukum dan bertanggungjawab atas operasional lembaga. Maju mundurnya lembaga koperasi lebih dominan ditentukan oleh pengurus. Anggota hanya menikmati produk layanan yang diberikan dan lebih fokus pada aspek hak dan kewajibannya saja di koperasi. Pengurus dapat juga dikatakan sebagai pemimpin, karena pengurus memimpin sekaligus sebagai pengelola koperasi sehingga peran pengurus dikatakan sebagai (board of director) atau dewan pengurus. Dewan pengurus artinya pengurus memiliki struktur yang sekurangkurangnya terdiri dari ketua, bendahara, dan sekretaris. Namun demikian, pengurus tidak dapat berbuat banyak apabila tidak didukung oleh semua pihak terutama peran serta anggota.

Menurut Undang-Undang Koperasi Nomor 25 Tahun 1992 pasal 30, tugas pengurus koperasi adalah Mengelola koperasi dan usahanya, Mengajukan rencana-rencana kerja serta rancangan rencana anggaran pendapatan dan belanja koperasi. Menyelenggarakan Rapat Anggota, Mengajukan laporan keuangan dan pertanggungjawaban pelaksanaan tugas. Menyelenggarakan pembukuan keuangan dan inventaris secara tertib. Memelihara daftar buku anggota dan pengurus, Selanjutnya Pengurus berwenang antara lain Mewakili koperasi di dalam dan di luar pengadilan, Memutuskan penerimaan dan penolakan anggota baru serta pemberhentian anggota sesuai dengan ketentuan dalam Anggaran Dasar. Melakukan tindakan dan upaya bagi kepentingan dan kemanfaatan koperasi sesuai dengan tanggung jawabnya dan keputusan Rapat Anggota.

Selain pengurus di dalam struktur koperasi ada yang disebut pengawas yaitu badan yang melakukan pengawasan manajemen koperasi. Menurut Teguh Sihono (2002 : 155), "pengawas merupakan pengendali atau pemeriksa pelaksanaan tugas yang dilakukan pengurus, apakah sudah sesuai dengan kebijakan yang ditetapkan Rapat Anggota atau belum". Tugas utama pengawas adalah mencari dan menemukan kemungkinan penyimpangan-penyimpangan pelaksanaan kebijakan yang dilakukan pengurus. Apabila ditemukan penyimpangan, pengawas harus mencari solusi atas penyimpangan yang terjadi.Pengawas dipilih oleh Rapat anggota dari kalangan anggota yang persyaratannya diatur dalam anggaran dasar koperasi. Masa jabatan pengawas tidak boleh lebih dari 5 tahun. Jika pengawas tidak mampu melaksanakan tugas pemeriksaan, koperasi dapat meminta bantuan jasa audit pada akuntan publik untuk melakukan pemeriksaan terhadap usaha koperasi, khususnya dalam bidang keuangan.

Untuk mengetahui kinerja karyawan dalam melaksanakan tugas-tugas yang menjadi tanggung jawab karyawan, maka perlu dilakukan penilaian terhadap kinerja pegawai. Penilaian kinerja bertujuan untuk menilai seberapa baik pegawai telah melaksanakan pekerjaannya dan apa yang harus mereka lakukan untuk menjadi lebih baik di masa mendatang. Ini dilaksanakan dengan merujuk pada isi pekerjaan yang mereka lakukan dan apa yang mereka harapkan untuk mencapai setiap aspek dari pekerjaan mereka. Isi dan suatu pekerjaan merupakan dasar tetap untuk perumusan sasaran yang akan dicapai dari suatu tugas utama yang dapat dirumuskan sebagai target kuantitas, standar kinerja suatu tugas atau proyek tertentu untuk diselesaikan. Dimensi yang dipergunakan di dalam melakukan penilaian kinerja pegawai menurut Prawirosentono (2003: 236), Pengetahuan atas pekerjaan, kejelasan pengetahuan atas tanggung jawab pekerjaan yang menjadi tugas karyawan. Perencanaan dan organisasi, kemampuan membuat rencana pekerjaan meliputi jadwal dan urutan pekerjaan, sehingga tercapai efisiensi dan efektivitas. Mutu pekerjaan, ketelitian dan ketepatan pekerjaan. Produktivitas, jumlah pekerjaan yang dihasilkan dibandingkan dengan waktu yang digunakan. Pengetahuan teknis, dasar teknis dan kepraktisan sehingga pekerjaannya mendekati standar kinerja. 6 . J u d g e $\mathrm{m}$ e $\mathrm{n} \mathrm{t}$, kebijakan naluriah dan kemampuan menyimpulkan tugas sehingga tujuan organisasi tercapai.

Komunikasi, kemampuan berhubungan secara lisan dengan orang lain. Kerjasama, kemampuan bekerja sama dengan orang lain dan sikap yang konstruktif dalam tim. Kehadiran dalam 
rapat, kemampuan dan keikutsertaan (partisipasi) dalam rapat berupa pendapat atau ide. Manajemen proyek, kemampuan mengelola proyek, baik membina tim, membuat jadwal kerja, anggaran dan menciptakan hubungan baik antar karyawan.

Kepemimpinan, kemampuan mengarahkan dan membimbing bawahan, sehingga tercipta efisiensi dan efektivitas. Kemampuan memperbaiki diri sendiri dengan studi lanjutan atau kursus-kursus.

Menurut Bernadin dan Russel (2003 : 109), Terdapat enam kriteria primer yang dapat digunakan untuk mengukur kinerja yaitu 1. Quality, merupakan tingkat sejauh mana proses atau hasil pelaksanaan kegiatan mendekati kesempurnaan atau mendekati tujuan yang diharapkan. 2 . Quantity, merupakan jumlah yang dihasilkan, misalnya jumlah rupiah, jumlah unit, jumlah siklus kegiatan yang diselesaikan. 3. Timeliness, adalah tingkat sejauhmana suatu kegiatan diselesaikan pada waktu yang dikehendaki, dengan memperhatikan koordinasi output lain serta waktu yang tersedia untuk kegiatan lain. 4. Costefectiveness, adalah tingkat sejauhmana penggunaan sumber daya organisasi (manusia, keuangan, teknologi, material) dimaksimalkan untuk mencapai hasil tertinggi, atau pengurangan kerugian dari setiap unit penggunaan sumber daya. 5 .

Need for supervision, merupakan tingkat sejauh mana seorang perkerja dapat melaksanakan suatu fungsi pekerjaan tanpa memerlukan pengawasan seorang supervisor untuk mencegah tindakan yang kurang diinginkan. 6. Interpersonal impact, merupakan tingkat sejauh mana karyawan memelihara harga diri, nama baik dan kerja sama antara rekan kerja dan bawahan.

Berdasarkan pendapat para ahli diatas, di dalam melihat kinerja seseorang, di dalam bekerja pada sebuah organisasi atau perusahaan dapat mengacu kepada dimensi kinerja ataupun kriteriakriteria kinerja. Dimensi tersebut akan memberikan gambaran yang jelas terhadap kinerja pegawai/ karyawan atau pengurus koperasi di dalam menjalankan tugas dan tanggung jawabnya. Setiap individu akan memiliki perbedaan dalam kinerja dan akan jelas terlihat kelebihan dan kelemahan masingmasing dengan menganalisis berdasarkan kriterikriteria kinerja tersebut.

Sedangkan penilaian kinerja yang efektif menurut Triton PB (2005 : 97-98) adalah apabila dalam penilaian kinerja tersebut benar-benar memperhatikan dan memprioritaskan dua hal berikut :1. Kriteria pengukuran kinerja memenuhi objektivitas. Untuk memenuhi persyaratan ini, maka ada tiga kualifikasi penting bagi pengembangan kriteria pengukuran kinerja yang objektif, yaitu meliputi :a.Relevansi, yang berarti harus ada kesesuaian antara kriteria dengan tujuan- tujuan kinerja. Misalnya apabila tujuan perusahaan adalah meningkatkan kualitas produksi dan penilaian kinerja dilakukan di bagian produksi, maka kualitas pekerjaan pegawai dijadikan kriteria lebih utama dibandingkan dengan keramahan.b.

Reliabilitas, yang berarti harus terpenuhinya konsistensi atas kriteria yang dijadikan ukuran kinerja. Dalam hal ini, cara melakukan pengukuran dan pihak yang melakukan penilaian kinerja turut mempengaruhi reliabilitas pengukuran.c.

Diskriminasi, yang berarti pengukuran dan penilaian kinerja harus mampu menunjukkan perbedaanperbedaan kinerja hasil pengukuran. Hasil pengukuran yang seragam, misalnya baik semua atau jelek. Semua menunjukkan tidak ditemukannya diskriminasi dalam penilaian kinerja.

Proses penilaian kinerja mempertahankan nilai objektivitas. Proses penilaian kinerja sangat penting diperhatikan. Objektivitas dalam proses penilaian berarti tidak adanya pilih kasih, pengistimewaan atau bahkan kecurangan dalam proses penilaian kinerja terhadap pegawai tertentu. Dalam hal indikator penilaian kinerja ini, Mahsun (2006:60) menyatakan sepuluh penilaian kinerja, yakni :1. Quality of work, yaitu kualitas kerja yang dicapai berdasarkan syarat-syarat yang telah ditetapkan.2. Quantity of work, yaitu jumlah kerja yang dilakukan dalam suatu periode waktu yang ditentukan.3. Job knowledge, yaitu pemahaman pegawai mengenai prosedur atau tata cara kerja serta informasi teknis tentang pekerjaan.4.Dependability, yaitu kemampuan untuk diandalkan khususnya dalam bekerja atau kemampuan menyelesaikan pekerjaan secara tepat sesuai dengan waktu yang ditentukan. 5.Adaptability, yaitu kemampuan beradaptasi atau kemampuan menanggapi kondisi dan perubahan yang terjadi di tempat kerja. 7 . Initiative, yaitu kemampuan memunculkan gagasan baru atau ide-ide baru berkaitan dengan pekerjaan.8. Problem Solving, yaitu kemampuan dalam melakukan tindakan-tindakan untuk menyelesaikan persoalan-persoalan yang timbul. 9. Attendence, yaitu hal-hal yang berkaitan dengan absensi atau sering tidaknya pegawai meninggalkan pekerjaannya.10. Cooperation, yaitu kesediaan bekerjasama dan berpartisipasi dengan pegawai lainnya baik secara vertikal maupun horizontal di dalam dan di luar pekerjaan.

Untuk melihat kinerja yang dilakukan oleh pengurus koperasi dapat menggunakan satu diantara teori yang dikemukakan para ahli diatas atau menggabungkan beberapa teori tersebut sehingga dapat saling melengkapi sehingga secara deskriptif kinerja pengurus koperasi dapat diketahui dengan lebih jelas dan objektif. Motivasi merupakan daya pendorong setiap orang dalam melakukan sesuatu, termasuk juga karyawan atau pegawai suatu perusahaan. Daya pendorong itu dapat dimiliki oleh setiap individu yang diperoleh dari berbagai faktor baik internal maupun eksternal individu. Sondang Siagian (2003:138) "mengemukakan bahwa motivasi berasal dari kata 
latin "movere" yang berarti "dorongan" atau daya penggerak". Dengan demikian motivasi adalah daya pendorong yang mengakibatkan seseorang anggota organisasi mau dan rela untuk mengerahkan kemampuan dalam bentuk keahlian atau ketrampilan tenaga dan waktunya untuk menyelenggarakan berbagai kegiatan yang menjadi tanggung jawabnya dan menunaikan kewajibannya, dalam rangka pencapaian tujuan dan berbagai sasaran organisasi yang telah ditentukan sebelumnya.

Selanjutnya menurut Grifin (2003:38) Motivasi adalah "sekelompok faktor yang menyebabkan individu berperilaku dalam cara-cara tertentu. Motivasi merujuk pada kekuatan-kekuatan internal dan eksternal seseorang yang membangkitkan antusiasme dan perlawanan untuk melakukan serangkaian tindakan tertentu". Motivasi karyawan mempengaruhi kinerja, dan sebagian tugas seorang manajer adalah menyalurkan motivasi menuju pencapaian tujuantujuan organisasional. Motivasi mempersoalkan bagaimana caranya mendorong gairah kerja bawahan, agar mereka mau bekerja keras dengan memberikan semua kemampuan dan keterampilannya untuk mewujudkan tujuan perusahaan. Motivasi berkaitan dengan bagaimana caranya mendorong gairah kerja bawahan, agar mereka mau bekerja keras dengan memberikan semua kemampuan dan keterampilannya untuk mewujudkan tujuan perusahaan.

Menurut Hasibuan (2003:95) bahwa motivasi kerja adalah "pemberian daya penggerak yang menciptakan kegairahan kerja seseorang agar mereka mau bekerja sama, bekerja efektif dan terintegrasi dengan segala daya upayanya untuk mencapai kepuasan". Faktor pendorong penting yang menyebabkan manusia bekerja adalah adanya kebutuhan yang harus dipenuhi. Dari pendapat para ahli diambil kesimpulan motivasi adalah berbagai usaha yang dilakukan oleh manusia tentunya untuk memenuhi keinginan dan kebutuhannya. Namun, agar keinginan dan kebutuhannya dapat terpenuhi tidaklah mudah didapatkan apabila tanpa usaha yang maksimal. Dalam pemenuhan kebutuhannya, seseorang akan berperilaku sesuai dengan dorongan seseorang akan berperilaku sesuai dengan dorongan yang dimiliki dan apa yang mendasari perilakunya.

Alderfer (Siagian (2003:166) mengungkapkan teori kebutuhan yang disebut teori ERG, ada tiga kelompok teori kebutuhan tersebut yaitu : a. Existence (Keberadaan), b. Relatednees (Keterikatan), c. Growth (Pertunbuhan). Teori ERG mengungkapkan bahwa sebagai tambahan terhadap proses kemajuan pemuasan juga proses pengurangan keputusan. Yaitu, jika seseorang terus-menerus terhambat dalam usahanya untuk memenuhi kebutuhan menyebabkan individu tersebut mengarahkan pada upaya pengurangan karena menimbulkan usaha untuk memenuhi kebutuhan yang lebih rendah. Penjelasan tentang teori ERG Aldefer menyediakan sarana yang penting bagi manajer tentang perilaku. Jika diketahui bahwa tingkat kebutuhan yang lebih tinggi dari seseorang bawahan misalnya, pertumbuhan nampak terkendali, mungkin karena kebijaksanaan perusahaan, maka hal ini harus menjadi perhatian utama manajer untuk mencoba mengarahkan kembali upaya bawahan yang bersangkutan memenuhi kebutuhan akan keterkaitan atau kebutuhan eksistensi. Teori ERG Aldefer mengisyaratkan bahwa individu akan termotivasi untuk melakukan sesuatu guna memenuhi salah satu dari ketiga perangkat kebutuhan.

David Mc Cleland (Siagian 2004 : 167) mengemukakan bahwa "pemahaman tentang motivasi akan semakin mendalam apabila disadari bahwa setiap orang mempunyai tiga jenis kebutuhan, yaitu: a. Kebutuhan akan berprestasi (Need forAchievement), b. Kebutuhan akan kekuasaan (Need for Power), c. Kebutuhan afiliasi (Need for Affiliation)". Teori hirarki kebutuhan dari Abraham Maslow menurut Sofyandi dan Garniwa (2007 : 102). terdiri dari 1. Kebutuhan fisiologis (Physiological-need), Kebutuhan Fisiologis Kebutuhan fisiologis merupakan hirarki kebutuhan manusia yang paling dasar yang merupakan kebutuhan untuk dapat hidup seperti makan, minum, perumahan, oksigen, tidur dan sebagainya. 2. Kebutuhan rasa aman (Safety-need), Apabila kebutuhan fisiologis relatif sudah terpuaskan, maka muncul kebutuhan yang kedua yaitu kebutuhan akan rasa aman. Kebutuhan akan rasa aman ini meliputi keamanan akan perlindungan dari bahaya kecelakaan kerja, jaminan akan kelangsungan pekerjaannya dan jaminan akan hari tuanya pada saat mereka tidak lagi bekerja. 3. Kebutuhan sosial (Social-need), Jika kebutuhan fisiologis dan rasa aman telah terpuaskan secara minimal, maka akan muncul kebutuhan sosial, yaitu kebutuhan untuk persahabatan, afiliasi dana interaksi yang lebih erat dengan orang lain. Dalam organisasi akan berkaitan dengan kebutuhan akan adanya kelompok kerja yang kompak, supervisi yang baik, rekreasi bersama dan sebagainya. 4. Kebutuhan penghargaan (Esteem-need), Kebutuhan ini meliputi kebutuhan keinginan untuk dihormati, dihargai atas prestasi seseorang, pengakuan atas kemampuan dan keahlian seseorang serta efektifitas kerja seseorang.5. Kebutuhan aktualisasi diri (Self-actualization need), Aktualisasi diri merupakan hirarki kebutuhan dari Maslow yang paling tinggi. Aktualisasi diri berkaitan dengan proses pengembangan potensi yang sesungguhnya dari seseorang. Kebutuhan untuk menunjukkan kemampuan, keahlian dan potensi yang dimiliki seseorang. Kebutuhan akan aktualisasi diri ada kecenderungan potensinya yang meningkat karena orang mengaktualisasikan 
perilakunya. Seseorang yang didominasi oleh kebutuhan akan aktualisasi diri senang akan tugastugas yang menantang kemampuan dan keahliannya.

Menurut Gomes (2003 : 180) bahwa motivasi seorang pekerja untuk bekerja biasanya merupakan hal yang rumit karena motivasi itu melibatkan faktor - faktor individual dan faktor faktor organisasional. Faktor - faktor yang termasuk individual antara lain kebutuhan kebutuhan (needs), tujuan - tujuan (goals), sikap (attitudes), dan kemampuan-kemampuan (abilities). Sedangkan yang tergolong pada faktor - faktor yang berasal dari organisasi meliputi pembayaran atau gaji, keamanan pekerjaan, harmonisasi sesama pekerja, pengawasan, pujian, dan pekerjaan itu sendiri.Fasilitas adalah segala sesuatu yang digunakan untuk bekerja sehingga tujuan yang diinginkan dalam pekerjaan dapat dicapai. Tanpa fasilitas maka pekerjaan tidak dapat dilaksanakan. Istilah lain dari fasilitas adalah sarana atau alat yang dipergunakan. Menurut samsudin (2009 : 13), "Fasilitas sendiri berasal dari bahasa belanda "faciliteit" yang artinya prasarana atau wahana sarana untuk melakukan atau mempermudah sesuatu". Menyadari akan pentingnya fasilitas bagi pengelola dalam bekerja maka perusahaan dituntut untuk menyediakan dan memberikan fasilitas kerja yang memadai agar kualitas dan kuantitas kerja dapat dihasilkan sesuai dengan yang diharapkan.

Syafri Sofyan (2001) mengemukakan jenis - jenis fasilitas kerja adalah Mesin dan peralatannya yang merupakan keseluruhan peralatan yang digunakan untuk mendukung proses produksi yang ada diperusahaan. Prasarana, yaitu fasilitas pendukung yang digunakan untuk memperlancar aktivitas perusahaan, diantaranya adalah jembatan, jalan, pagar dan lainnya. Perlengkapan kantor, yaitu fasilitas yang mendukung aktivitas kegiatan yang ada di perkantoran, seperti perabot kantor (meja, kursi, lemari, dan lainnya). Fasilitas kerja pada setiap organisasi tentu berbeda-beda sesuai dengan aktivitas yang dilakukan, pada perusahaan manufaktur maka lebih banyak penggunaan mesinmesin yang dipergunakan untuk proses produksi, begitu pula pada pekerjaan pelayanan publik maka lebih banyak peralatan yang berhubungan dengan pekerjaan administrasi perkantoran seperti komputer, meja, kursi, kertas, dan alat tulis kantor lainya. Menurut Alex S. Nitisemito (2000 : 34) bahwa jenis - jenis fasilitas yang menyenangkan dapat ditafsirkan secara luas antara lain tempat rekreasi kafetaria, tempat olahraga, balai pengobatan, tempat ibadah, kamar kecil yang bersih, pendidikan untuk anak dan sebagainya. Lebih lanjut, indikator fasilitas menurut Faisal (Ermiati dan Sembiring 2012 : 79) adalah “(1) Komputer, (2) meja kantor, (3) parkir, (4) bangunan kantor, (5) transportasi"'.

Berdasarkan pendapat ahli diatas bahwa perusahaan memerlukan fasilitas atau sarana dan prasarana. Ada yang dikategorikan sebagai fasilitas utama dan fasilitas pendukung. Fasilitas utama merupakan alat-alat yang harus ada yang digunakan secara langsung dalam proses kerja misalnya komputer untuk pekerjaan administrasi, alat tulis seperti kertas, pulpen, kalkulator, map, lemari, meja, kursi dan sebagainya. Sementara fasilitas pendukung adalah sarana yang digunakan untuk menunjang kegiatan agar produktivitas kerja lebih baik. Fasilitas pendukung misalnya tersedia kipas angin, AC, dispenser, televisi, dan lain-lain yang dapat memberikan kemudahan dan kenyamanan dalam bekerja.

\section{METODE PENELITIAN}

Penelitian ini merupakan penelitian deskriptif dengan analisis data kualitatif. Subjek penelitian ini adalah Ketua Pengurus, Ketua Pengawas, dan Anggota KUD Dharma Bhakti yang terletak di Kecamatan Binjai Hilir Kabupaten Sintang. Teknik Pengumpulan data dengan menggunakan wawancara, observasi, dan dokumentasi. Selanjutnya penelitian dilakukan dengan menggunakan alat berupa pedoman wawancara, pedoman observasi, dan alat-alat untuk pedokumentasian. Data yang diperoleh dianalisis berdasarkan teknik analisis kualitatif yang dilakukan melalui tiga alur kegiatan yaitu : reduksi data, penyajian data dan penarikan kesimpulan/verifikasi. Teknik analisis juga mendasarkan pada ketiga alur kegiatan analisis tersebut, yang pada dasarnya dapat terjadi pada waktu yang bersamaan. Jadi pada saat melakukan reduksi data dapat juga pada saat itu sekaligus dilakukan pembuatan format penyajian data yang memungkinkan untuk penarikan kesimpulan.

\section{HASIL PENELITIAN DAN PEMBAHASAN}

Kinerja pengurus menjadi penentu perkembangan dan kemajuan KUD Dharma Bhakti di Kecamatan Binjai. Sebagai koperasi mitra perusahaan perusahaan PT. Bonti Permai Jayaraya yang bergeral dalam perkebunan kelapa sawit menjadi wadah yang diharapkan dapat memfasilitasi kepentingan anggota petani plasma kelapa sawit. Pengurus dipercaya oleh anggota untuk menjalankan roda usaha organisasi koperasi untuk kemajuan bersama. 
Tugas pokok dan fungsi pengurus adalah sebagai berikut :

1. Tugas pokok pengurus yaitu :
a. Mengelola koperasi berdasarkan Anggaran Dasar
b. Mengajukan rancangan rencana kerja dan rancangan rencana anggaran pendapatan dan belanja koperasi
c. Menyelenggarakan rapat anggota
d. Mengajukan laporan keuangan dan pertanggung jawaban pelaksanaan tugas
e. Menyelenggarakan pembukuan keuangan dan inventaris secara tertib

2. Fungsi pengurus yaitu :
a. Menyelenggarakan dan mengendalikan usaha koperasi
b. Melakukan seluruh perbuatan hukum atas nama koperasi
c. Mewakili koperasi didalam dan diluar pengadilan
d. Mengajukan rencana kerja, anggaran pendapatan dan belanja koperasi
e. Menyelenggarakan rapat anggota serta mempertanggungjawabkan pelaksanaan tugas kepengurusan.
f. Membantu pelaksanaan tugas pengawasan dengan memberikan keterangan dan memperlihatkan bukti- bukti yang diperlukan.

Berdasarkan Tupoksi pengurus, dapat diketahui bahwa pengurus koperasi merupakan organ organisasi yang menduduki posisi trategis dalam struktur organisasi koperasi. Pengurus memiliki wewenang menjalankan koperasi berdasarkan aturan yang termuat di dalam Anggaran Dasar sebagai instumen hukum yang mengatur koperasi dan pengurus. Pengurus diangkat berdasarkan keputusan Rapat Anggota. Dengan demikian Rapat Anggota adalah kekuasaan tertinggi di dalam koperasi. Jabatan pengurus pada KUD Dharma Bhakti terdiri dari Ketua pengurus, Bendahara, dan Sekretaris. Ketua Pengurus KUD bertindak selaku pemimpin tertinggi dalam kepengurusan, namun bukan sebagai pemegang kekuasaan tertinggi dalam organ KUD. Walaupun bukan sebagai pemegang kekuasaan tertinggi tetapi dalam prakteknya (defacto), banyak arah dan kebijakan lembaga terletak pada keputusan ketua pengurus. Ketua pengurus bersama anggota pengurus lain dapat membuat kebijakan pengurus sebagai bentuk dari jabaran program kerja. Ketua pengurus melakukan inisiasi berbagai program untuk kaji dan direncanakan untuk dibuat suatu produk yang ditawarkan ke konsumen.

Organ pengurus selanjutnya adalah bendahara, bendahara memiliki wewenang dan tanggung jawab dalam ruang lingkup kepengurusan dalam bidang yang lebih spesifik berkaitan manajemen keuangan koperasi. Fungsi bendahara membantu ketua pengurus untuk melakukan perencanaan dan rancangan rencana angggarran pendapatan dan belanja koperasi, menghimpun data-data transaksi keuangan, mengklasifikasikan, dan menyusun laporan keuangan secara periodik. Pencatatan keuangan menjadi tanggung jawab bendahara dalam menyelesaikannya. Pencatatan dan pembukuan yang harus diselesaikan secara garis besar meliputi semua jenis laporan keuangan, yaitu laporan neraca, rugi laba, perubahan modal, dan arus kas.

Bendahara KUD bertanggung jawab atas semua aspek administrasi keuangan, sehingga tidak terbatas pada pekerjaan membuat laporan keuangan saja, tetapi termasuk melakukan kajian dan analisis dari perkembangan organisasi berdasarkan aspek keuangan. Melakukan perhitungan dan analisis dari rasio-rasio laporan keuangan setiap periode untuk selanjutnya dijadikan laporan yang disampaikan kepada ketua pengurus. Selanjutnya sekretaris KUD merupakan organ pengurus yang memiliki cakupan rentang tanggung jawab dan tugas yang berkaitan dengan administrasi umum organisasi. Jabaran tugas dan fungsi sekretaris pengurus antara lain, yaitu : 1. Memastikan surat menyurat dibuat sesuai dengan kepentingan, selesai dibuat dan diperlukan tepat waktu. Bila surat tersebut ditujukan ke pihak-pihak yang berkepentingan dipastikan sampai dan dapat dipahami maksud dan tujuan surat tersebut oleh penerima.2. Memastikan pengarsipan surat - surat tersimpan dengan rapi dan baik serta mudah ditemukan. 3.Membuat jadwal rapat pengurus dan rapat anggota setelah berkoordinasi dengan ketua pengurus.4.Menjadi notulen dalam rapat-rapat

Tupoksi menurut penjelasan ketua pengawas pada prinsipnya adalah menjalankan program kerja tahunan, bulan, dan harian. Melaksanakan fungsi eksekutif organisasi. Merancang, merumuskan, menetapkan, dan mengimplementasikan program. Dengan demikian fungsi pengurus melaksanakan fungsi manajerial dan teknis. Menurut ketua pengawas, untuk fungsi teknis operasional sebetulnya bisa saja pengurus merekrut pegawai untuk melaksanakan tugas-tugas harian, tetapi dengan berbagai pertimbangan hal tersebut belum dapat diwujudkan. Oleh sebab itu fungsi pengurus memegang fungsi yang sangat strategis untuk membawa KUD menjadi sebuah lembaga yang sesuai dengan cita-cita untuk melayani kepentingan anggota. Pengurus menjadi penentu perjalanan organisasi koperasi, berkembang atau tidaknya koperasi terletak pada pengurus. Pengurus diharapkan bagaimana mengelola usaha dengan baik. Apabila pengelolaan lembaga baik oleh pengurus maka lembaga koperasi dapat berkembang. Sehubungan dengan pengelolaan KUD Dharma Bhakti oleh pengurus menuruut ketua pengawas, selama ini sudah 
menunjukkan keseriusan pengurus di dalam mengelola lembaga KUD. Hal ini ditunjukkan diselenggarakannya KUD berdasarkan peraturan perundang-undangan yang berlaku dan ketentuan pada Anggaran Dasar. KUD Dharma Bhakti selama ini mampu memenuhi kewajiban melaksanakan Rapat Anggota Tahunan (RAT). Pengurus juga berdasarkan hasil pengawasan melaksanakan pelayanan setiap hari, yaitu hari senin sampai dengan hari jumat. Menurut ketua pengawas, hal tersebutkan menunjukkan upaya pengurus dalam menjalankan tupoksinya. Selain itu tanda berjalannya fungsi pengurus adalah dibuatnya laporan pertanggung jawaban pengurus setiap akhir tahun dan dibuatnya program kerja untuk tahun buku berikutnya. Pengawas melakukan pengawasan berdasarkan laporan keuangan yang dibuat oleh pengurus. Pengawas memastikan apakah laporan yang dibuat sudah baik dan benar. Selain itu pengawas juga melakukan monitoring pada pelaksanaan pelayanan yang dilakukan pengurus. Berdasarkan hasil monitoring pengawas, pengurus sudah menjalankan tupoksinya baik sebagai pembuat kebijakan, maupun sebagai pelaksana tugas operasional lembaga.

Dalam hal kuantitas kerja pengurus telah melaksanakan pelayanan pada bidang-bidang antara lain mengelola usaha simpan pinjam anggota, yaitu simpanan pokok dan simpanan wajib anggota, dan pinjaman (kredit). Selanjutnya pengelolaan sarana produksi perkebunan kelapa sawit, seperti pupuk, herbisida, obat-obatan, dan sebagainya. Pengurus juga mengelola transportasi pengangkutan produksi buah kelapa sawit petani. Hal-hal yang diuraikan tersebut diatas merupakan dimensi kinerja dalam aspek kuantitas kerja. Sementara dalam aspek kualitas berkaitan dengan mutu kerja yang dihasilkan oleh pengurus. Mutu kerja yang dihasilkan oleh pengurus KUD Dharma Bhakti sudah dapat diterima oleh anggota, walaupun ada anggota yang masih tidak puas. Ketidakpuasan anggota bukan kerena mutu kerja pengurus yang tidak baik tetapi karena faktor subjektivitas anggota, yaitu karena kepentingan individual anggota yang merasa tidak dapat dipenuhi.

Dalam hal kualitas kerja, Pengurus telah melaksanakan tupoksi dengan baik sesuai dengan peran masing-masing. Secara administrasi, baik administrasi umum maupun administrasi keuangan telah dilakukan secara maksimal oleh Sekretaris dan bendahara Pengurus. Pengurus juga sudah melaksanakan Rapat Anggota Tahun setiap tahunnya sebagai bentuk pertanggungjawaban kerja Pengurus kepada anggota dan penyampaian program kerja tahun buku periode berikutnya. Dalam hal kualitas, pekerjaan masing-masing pekerjaan memiliki standar kinerja yang harus dicapai. Standar kerja untuk laporan keuangan adalah mengacu kepada laporan akuntansi yang standar yang mencantumkan neraca, laporan rugi laba, arus kas dan perubahan modal.

Selanjutnya dimensi kinerja yang berhubungan dengan kecepatan, ketepatan, dan ketelitian menurut ketua pengurus masih ada kekurangannya. Pengurus dalam bekerja diakui masih lambat dalam menyelesaikan suatu pekerjaan, namun selama ini masih mampu menyelesaikan sesuai dengan batas waktu yang ditentukan. Terkadang juga pengurus kurang teliti di dalam melakukan pencatatan dan pembukuan sehingga membuat pekerjaan diulang untuk mengecek catatan yang tidak sesuai. Dalam proses pengerjaan laporan keuangan juga sering kali salah, sehingga pembukuan dapat terjadi selisih. Tetapi pengurus berusaha untuk menemukan letak selisih angka pembukuan tersebut dan dipastkan harus benar sebelum laporan disampaikan ke pengawas atau anggota.

Dimensi kinerja selanjutnya menurut ketua pengurus adalah kerjasama tim. Pengurus di dalam pengelolaan melakukan kerjasama secara internal dan eksternal organisasi. Secara internal pengurus bekerja sama di dalam kepengurusan, yaitu ketua, bendahara, dan sekretaris saling bekerjasama untuk menghasilkan pelayanan koperasi yang baik. Kerja sama tentu dalam hal koordinasi dan komunikasi, memberi arahan, petunjuk dan mengajukan usul saran, pertanyaan untuk suatu pekerjaan dan program kerja. Kerja sama pengurus melakukan komunikasi yang berjalan secara dinamis dilakukan dalam semangat kebersamaan untuk satu tujuan bersama di dalam KUD. Kerja sama dalam kepengurusan menurut Ketua koperasi sudah berjalan baik yang diwujudkan dengan komunikasi yang baik dan menjalankan tugas dan fungsinya masing-masing. Tugas ketua lebih kepada membuat rancangan kebijakan yang strategis yang kemudian disampaikan kepada tim pengurus untuk mendapat usul saran. Selanjutnya di dalam tim ketua pengurus juga sebagai pemimpin yang mengerakan yang lain, memberikan motivasi, dan mengarahkan di dalam proses pelaksaan tugas yang lain.

Kerja sama eksternal, pengurus bekerja sama dengan pengawas, menerima masukanmasukan dari pengawas berupa saran dan koreksi bila ada yang perlu diusulkan dan diperbaiki terkait program dan pelaksanaan operasional kegiatan KUD. Sebagai bentuk kerja sama, pengawas meminta laporan keuangan, dan laporan pertangung jawaban pengurus, kemudian pengurus memberikannya, selanjutnya proses pemeriksanaan oleh pengawas dilakukan. Kerja sama pengurus juga dilakukan dengan anggota KUD. Kerja sama ini dalam bentuk pelayanan pengurus kepada anggota, dan anggota melaksanakan kewajiban sesuai dengan ketentuan yang disepakati dalam rapat anggota. Sebagai anggota, maka anggota yang baik harus berpartisipasi aktif dan 
melaksanakan kewajiban dan mentaati semua peraturan koperasi.

Kinerja pengurus dapat dilihat dari beberapa aspek antara lain kemampuan kepemimpinan, teknis, dan hubungan masyarakat. Pengurus KUD Dharma Bhakti memiliki aspek kepemimpinan yang terlihat dari kemampuan dalam pengelolaan, koordinasi, komunikasi, kerja sama tim, dan dapat menyelesaikan persoalanpersoalan. Dalam pengelolaan, Pengurus KUD telah menerapkan fungsi-fungsi dari manajemen yaitu melakukan perencanaan dengan membuat perencanaan program kerja dan program tersebut dibuat secara tertulis sebagai bentuk pelaporan dalam RAT. Program yang disampaikan berisikan tentang rencana pendapatan dan belanja/biaya KUD. Selain itu program juga berisikan data-data target capaian non keuangan seperti kebijakankebijakan yang akan ditetapkan untuk menjalankan koperasi.

Pada fungsi pengoorganisasian, masa jabatan pengurus selama 3 tahun sehingga perlu direncanakan kaderisasi kepengurusan untuk periode setelah jabatan pengurus berakhir. Perlu dilakukan pendataan anggota-anggota yang potensial untuk dicalonkan menjadi pengurus. Pelaksanaan pemilihan pengurus dilaksanakan dalam rapat anggota. Selain itu pengurus juga merencanakan untuk keberlangsungan badan pengawas, mengingat pengawas juga memiliki masa kerja/jabatan selama 3 tahun. Oleh karena itu tim pengawas juga harus dipikirkan oleh pengurus untuk periode-periode selanjutnya. Kelemahan dalam organisasi KUD Dharma Bhakti belum memiliki penasehat sebagai bagian di dalam struktur koperasi yang biasanya ada. Bagian ini memiliki fungsi yang penting di dalam memberikan gagasan sehingga dapat memberikan usul dan saran kepada pengurus maupun pengawas. Bagian penesehat ini menjadi bagian dalam perencanaan pengoorganisasian pengurus aktif untuk mempertimbangkan periode yang akan datang untuk di isi oleh individu anggota potensial.Pada fungsi actuating (pelaksanaan), pengurus telah melaksanakan program kerja sesuai dengan rancangan program kerja yang telah dibuat pada tahun lalu. Bidang usaha yang dilakukan pengurus yaitu : 1. Unit Usaha pelayanan jasa dan angkutan Tandan Buah Segar (TBS) kelapa sawit. KUD Dharma Bhakti dalam unit usaha ini melakukan kemitraan dengan PT. Bonti Permai Jayaraya dengan pola KKPA. Unit usaha ini memberikan kemudahan bagi petani dan pihak perusahaan dalam pelayanan jasa dan angkutan TBS kelapa sawit, guna memudahkan angkutan buah kelapa sawit ke pabrik. 2. Unit usaha simpan pinjam, yaitu usaha KUD dalam kegiatan menghimpun dan menyalurkan dana kepada anggota dengan bunga yang rendah. Tujuan dari unit usaha simpan pinjam adalah mengusahakan keperluan kredit bagi para anggota dengan syarat-syarat yang ringan. Sumber utama modal pinjaman keanggota adalah simpanan anggota ditambah dengan Sisa Hasil Usaha Koperasi. 3. Unit usaha Bahan Bakar Minyak (BBM), Kegiatan unit usaha ini merupakan usaha KUD dalam penyediaan BBM jenis solar yang bertujuan untuk para sopir yang melakukan angkutan TBS ke pabrik. 4. Unit Usaha Sarana Produksi Tani (Saprodi), Yaitu kegiatan KUD dalam penyediaan sarana produksi yang dibutuhkan seperti herbisida, pupuk, obat pemberantasan hama, dan sarana kerja dalam pengelolaan dan pemanenan.

Motivasi dapat mempengaruhi kinerja setiap orang, seseorang yang memiliki motivasi yang rendah maka tidak akan mengupayakan kerja secara maksimal sehingga produktivitas kerja rendah yang selanjutnya kinerja pasti rendah. Demikian sebaliknya untuk orang yang memiliki motivasi tinggi maka akan memiliki semangat yang tinggi yang selanjutnya dapat membuat produktivitas juga meningkat. Semua pengurus memiliki motivasi yang tinggi terhadap pekerjaan. Motivasi tersebut karena kesadaran akan tanggung jawab sosial kepada anggota. Orientasi pengurus di dalam mengurus lembaga tidak hanya untuk kepentingan diri sendiri tetapi lebih kepada kepentingan bersama. Pengurus merasa bahwa tanggung jawab yang diberikan anggota untuk mengelola koperasi merupakan suatu kepercayaan anggota sehingga kepercayaan tersebut harus dijaga dengan baik.

Motivasi pengurus dan pengawas dalam bekerja karena ada kepentingan bersama, yaitu memajukkan lembaga koperasi agar berkembang. Pengurus dan pengawas serta anggota menyadari pentingnya wadah koperasi tersebut untuk mengakomodir kepentingan dalam urusan pengelolaan kebun kelapa sawit milik petani mitra yang bermitra dengan perusahaan. Motivasi pengurus untuk mengurus koperasi juga didukung oleh kompensasi yang diberikan oleh lembaga koperasi kepada pengurus. Kompensasi yang diterima oleh pengurus berupa insentif yang diterima dalam bentuk uang sebagai jasa pengelolaan KUD oleh pengurus. Besarnya insentif yang diterima oleh pengurus bervariasi sesuai dengan jabatannya di dalam kepengurusan. Jumlah insentif yang diterima oleh ketua pengurus sebesar Rp. 1.500.000,sedangkan untuk bendahara dan sekretaris sebesar Rp. 1.000 .000 per bulannya. jumlah tersebut sudah ditentukan dalam rapat pengurus dan pengawas serta telah disetujui oleh anggota KUD. Jumlah tersebut sebenarnya masih rendah bila dibandingkan gaji pegawai atau karyawan berdasarkan standar upah minimum kabupaten. Namun jumlah insentif pengurus sudah dipertimbangan dan diputuskan dengan matang berdasarkan musyawarah pengurus dan pengawas. Jumlah tersebut disesuaikan dengan kemampuan lembaga KUD. 
Sumber pendapatan pengurus bukan hanya insentif yang diterima dari koperasi saja. Pengurus juga bagian dari masyarakat yang bekerja sebagai petani dan pekebun sehingga sumber pendapatan juga berasal dari usahatani. Pengurus masih dapat melaksanakan pekerjaan lain selain mengurus KUD. Waktu kerja pengurus mulai dari hari senin sampai hari jumat, sehingga masih memungkin pengurus melaksanakan pekerjaan lain pada hari sabtu dan hari minggu. Selain itu dari hari senin sampai jumlah juga ada waktu kosong yang bisa dimanfaatkan pengurus melakukan pekerjaan yang lainnya. Jam kerja pengurus mulai dari jam 9 pagi sampai jam 2 siang sehingga masih ada waktu sebelum masuk kerja di KUD dan setelah pulang kerja.

Pengurus bekerja memiliki motivasi kerja. Hal ini ditunjukkan dengan pelayanan yang mereka lakukan terhadap anggota. Kebutuhan anggota dapat pengurus layani dengan baik sesuai dengan bidang usaha dan kapasitas yang dapat dilakukan. Kendala yang ada adalah tidak semua anggota memahami kondisi dan mekanisme kerja KUD. Terkadang barang yang diperlukan tidak tersedia sarana produksi dan pengangkutan. Kendala tersebut menjadi hambatan dalam pengelolaan kebun sehingga dapat menyebabkan tidak sesuainya jadwal pemeliharaan dan pengangkutan. Kendala yang terjadi tersebut tidak semua anggota dapat memahaminya sehingga dapat dengan mudah menyalahkan pihak pengelola KUD.

Tidak tersedianya sarana yang diperlukan disebabkan oleh faktor distribusi dari penyalur/agen yang terhambat. Misalnya terkadang dapat terjadi kelangkaan solar sebagai bahan bakar untuk kendaraan pengangkut TBS. Tidak tersedianya pupuk untuk tanaman sawit, pupuk dapat mengalami kekurangan stok di pasar sehingga terhambatnya distribusi pupuk ke petani. Kendalakendala tersebut mempengaruhi pelayanan pengurus kepada anggota, sering kali anggota menjadi kesal dan cendrung menyalahkan pengurus. Bagi anggota yang mengerti maka dapat menerima penjelasan pengurus mengenai kendalakendala yang ada.Motivasi dipengaruhi oleh beberapa faktor baik faktor sosial, ekonomi, budaya dan lingkungan. Motivasi pengurus dari faktor sosial berkaitan dengan rasa tanggung jawab pengurus atas kepercayaan yang telah diberikan oleh anggota untuk mengelola koperasi. Dengan semangat mengembangkan koperasi untuk kepentingan bersama merupakan pertimbangan dari aspek sosial pengurus. Selanjutnya aspek ekonomi berkaitan dengan kepentingan bersama untuk kesejahteraan, dan berkaitan dengan sosial yaitu kesejaheraan bersama melalui wadah koperasi. Pengurus secara ekonomi menerima jasa pengelolaan sehingga dapat menambah income/ pedapatan keluaga, selain itu juga mendapat manfaat pengelolaan koperasi untuk kepentingan kebun sawit milik keluarga pengurus.
Berdasarkan aspek budaya, motivasi pengurus dipengaruhi oleh gaya hidup, pola kerja, dan sistem dan wadah ekonomi yang berlaku di masyarakat. Koperasi khususnya KUD merupakan lembaga yang sudah ada dan berkembang sebagai bagian dari sistem ekonomi masyarakat dipedesaan. Selain KUD juga banyak berkembangan lembaga ekonomi yang sudah membudaya seperti Credit Union dan koperasi simpan pinjam yang lainnya. Lembaga koperasi sudah familiar ditengah-tengah masyarakat sehingga merupakan bagian dari lembaga keuangan non bank yang dirasakan sangat membantu masyarakat pedasaan khususnya masyarkat petani dan perkebunan kelapa sawit.

KUD Dharma Bhakti selain sebagai wadah untuk mengakomodir kepentingan petani dalam hal sarana produksi kelapa sawit juga melayani simpan pinjam anggota sehingga dapat membantu anggota yang memerlukan bantuan dana dalam memenuhi berbagai keperluan hidup keluarga. Produk pinjaman diarahkan untuk meningkatkan produktivitas usaha dan memenuhi keperluan konsumsi keluarga. Pinjaman yang diberlakukan dengan kredit bunga ringan serta persyaratan yang mudah sehingga diharapkan benar-benar dapat bermanfaat dan mengangkat taraf hidup anggota.

Pengurus merasa termotivasi dari aspek ekonomi ini karena dapat memajukan perekonomian anggota. Pengurus merasa bangga apabila anggota tertolong secara ekonomi melalui wadah KUD. Namun pengurus dihadapkan pada tantangan untuk pembinaan anggota yang belum sepenuhnya memahami keberadaan KUD dan prinsip-prinsip pengelolaan ekonomi rumah tangga.

Kemudian dari aspek lingkungan, KUD memungkinkan untuk di dirikan di tengah masyarakat yang mayoritasnya adalah masyarakat ekonomi menengah kebawah dan masih ada yang dibawah garis kemiskinan. Perkebunan kelapa sawit merupakan komoditas yang dikelola masyarakat dan perkebunan di seluruh wilayah di Kalimantan Barat, khususnya di kecamatan Binjai Hilir. Setiap perusahaan biasanya memiliki kebun plasma sebagai kebun milik petani yang dikelola perusahaan dengan sistem mitra. Pendirian kebun plasma memerlukan wadah yang mengkoordinir lebih lanjut dari perusahaan sehingga diperlukan KUD.

Fasilitas kerja merupakan barang atau alat yang diperlukan pengurus untuk melakukan proses pekerjaan atau pengelolaan KUD. Fasilitas tersebut merupakan bagian dari sumber daya organisasi yang sangat menentukan kinerja pengurus, mengingat tanpa alat atau sarana prasarana yang memadai maka akan menghambat proses pekerjaan.KUD Dharma bhakti dalam pengelolaan usaha memerlukan fasilitas yang digunakan untuk bekerja terutama yang berkaitan dengan fasilitas yang digunakan untuk pekerjaan administrasi perkantoran. Fasilitas yang dipergunakan di kantor 
KUD sudah cukup memadai sehingga tidak ada kendala dalam melaksanakan pekerjaan operasional kantor. Fasilitas tersebut dianggap fasilitas yang utama harus ada agar kegiatan dapat berjalan lancar.

Fasilitas kantor di KUD dapat dimanfaatkan dengan baik oleh pengurus. Pengurus dapat melaksanakan pekerjaan kantor dan pelayanan ke anggota dengan menggunakan fasilitas yang ada. Kinerja pengurus dipengaruhi juga oleh fasilitas, ruang yang bersih, sejuk, dan luas ruangan yang memadai memungkinkan pengurus untuk berkerja lebih nyaman dan tenang sehingga dari aspek fasilitas sangat membantu. Namun lebih lanjut menurut ketua pengawas, dalam pengoperasian komputer tidak sepenuhnya pengurus menguasainya. Masih ada kendalakendala dalam pengoperasian komputer. Tidak semua pengurus menguasai program komputer dasar seperti program word, excel, dan powerpoint. Hal ini terlihat ketika mengetik juga belum bisa lancar dan cepat, begitu pula dalam menggunakan program excel, walaupun dapat menggunakannya tetapi belum fasih, karena masih terlihat ketikan yang tidak tertata dengan rapi. Dilihat dari fasilitas yang ada, sudah memadai digunakan oleh pengurus untuk menjalankan aktivitas di KUD Dharma Bakti. Letak kantor pun mudah dijangkau oleh anggota karena di berada di wilayah anggota di Kecamatan Binjai Hilir. Bangunan kantor terletak diwilayah yang strategis, yang bisa dijangkau oleh anggota menggunakan kendaraan sepeda motor maupun mobil sehingga mudah untuk diakses untuk urusan ke KUD.

\section{KESIMPULAN DAN SARAN}

Tugas Pokok dan fungsi pengurus KUD Dharma Bhakti sudah ditetapkan dan dapat dilaksanakan dengan baik. Pengurus terdiri dari ketua, bendahara, dan sekretaris yang memiliki tupoksi masing-masing dalam menjalankan operasional usaha KUD. Bidang usaha KUD yang dijalankan pengurus yaitu : 1) Pelayanan jasa angkutan Tandan Buah Segar (TBS) kelapa sawit anggota/petani plasma. 2) usaha simpan pinjam anggota, 3) pengadaan sarana produksi perkebunan kelapa sawit dan 4) pengadaan bahan bakar minyak untuk pengangkutan. Pengurus dalam bekerja telah menunjukkan kinerja yang baik ditinjau dari dimensi kinerja seperti kualitas, kuantitas, kecepatan kerja, kerja sama, kepemimpinan, dan komunikasi. Pengurus memiliki motivasi yang tinggi dalam mengelola KUD yang ditunjukkan dengan kesungguhan dalam bekerja. Faktor-faktor yang memotivasi adalah rasa solidaritas, kepercayaan yang diberikan anggota (rasa tanggung jawab), dan jasa honor yang diberikan KUD. Pengurus di dalam melaksanakan tupoksinya sudah didukung dengan fasilitas-fasilitas yang memadai berupa gedung kantor yang besar, meja, kursi, dan alat tulis kantor yang memadai. Perlu upaya meningkatkan kinerja Pengurus sebaiknya dapat dilakukan dengan memberikan motivasi kerja berupa peningkatan kompensasi. Pelatihan dan pendidikan pengurus perlu ditingkatkan agar kompetensi pengurus meningkat. Sebaiknya perlu dipertimbangkan untuk menambah fasilitas pengurus untuk lebih melancarkan kegiatan operasional.

\section{DAFTAR PUSTAKA}

Alex S. Nitisemito. 2000. Manajemen Personalia. Jakarta : Ghalia Indonesia.

Arikunto, S. 2002. Metode Penelitian Kualitatif. Yogyakarta : Bumi Aksara.

Bernadin, H Hon dan Hoyce, EA. Russel. 2003. Human Resources Management. Mc Graw Hill Inc, Singapore.

Ermiati dan Sembiring. 2012. "Pengaruh Fasilitas dan Pengembangan Sumber Daya Manusia terhadap Produktivitas Kerja Karyawan Studi Kasus PTPN II Kebun Sampali Medan”. Jurnal Darma Agung. Vol 1. Hal $8-20$.

Gomes F.C. 2003. Manajemen Sumber Daya Manusia. Yogyakarta : ANDI.

Grifin, R.W. 2003. Manajemen. Jakarta : Erlangga.

Hasibuan, M. 2003. Organisasi dan Motivasi. Dasar Peningkatan Produktivitas. Jakarta: Bumi Aksara.

Hasibuan, Malayu . 2002. Manajemen Sumber Daya Manusia. Bumi Aksara. Jakarta.

Hendrojogi. 2005. Koperasi : Asas - asas, Teori, dan Praktik Edisi Empat. Jakarta : PT. Raja Grafindo Persada.

Mahsun. 2006. Pengukuran Kinerja Sektor Publik : Cetakan Pertama. Yogyakarta : Penerbit BPFE - Yogyakarta.

Mangkunegara, 2005. Evaluasi Kinerja Sumber Daya Manusia. Cetakan I. Bandung: PT Refika Aditama.

Pandji Anaroga dan Ninik W. 1983. Dinamika Koperasi. Cetakan kelima. Jakarta : PT. Reneka Cipta.

Prawirosentono, Suyadi. 2003. Manajemen Sumber Daya Manusia. (Kebijakan Kinerja Karyawan), Yogyakarta : BPFE.

Samsudin. 2009. Sumber Daya Manusia. Bandung : Rineka Cipta.

Satori, D dan Komariah, A. 2014. Metode Penelitian Kualitatif. Bandung: Alfabeta.

Siagian P. Sondang. 2003. Teori motivasi dan Aplikasinya . Edisi 3. Jakarta: PT. Rineka Cipta.

Sofyandi dan Garniwa. 2007. Perilaku Organisasional. Edisi Pertama. Yogyakarta Graha Ilmu.

Syafri Sofyan. 2001. Sistem Pengawasan Manajemen. Jakarta : Quantum.

Triton, P.B 2005. Riset Statistik Parametrik : Yogyakarta: Andi.

Widayanti. 2005. Ekonomi 2. Bandung: Angkasa. Peraturan Perundang-Undangan :

Undang - Undang Nomor 25 tahun 1992 tentang perkoperasian. 